\title{
ON THE LATER EMBRYOLOGICAL STAGES OF THE HEAD OF PRISTHESANCUS PAPUENSIS. (REDUVIIDAE)
}

\author{
By F. Muir and J. C. Kershaw.
}

Mossman, North Queensland.

The authors, in a former paper, ${ }^{*}$ based on anatomical studies of the adult heads of Hemiptera, drew certain conclusions as to the homologies of their mouth-parts. Wishing to see if these conclusions could be verified by embryology, the studies herein described were undertaken on the embryo of Pristhesancus papuensis.

For our present purpose it is only necessary to begin our descriptions from the fifth day after the eggs were laid.

5th day. (Fig. 1) At this stage the embryo is in a dorsoventral position. The procephalic lobes are large, and the antennæ distinct. All the appendages are distinct, but the 1st maxillæ are plain, single lobes, as are also the 2nd maxillæ. There is no sign of the eyes. Two small lobes over the stomodæum represent the labrum.

6th day. (Fig. 2) There is a deep constriction between the procephalic lobe and base of antenna. The appendages are longer and the legs have two distinct joints. The embryo has a posterio-ventral position.

7th day. (Fig. 3) The first maxillæ are now two-jointed, the basal joint we will distingusih as the maxillary plate, the distal as the maxillary seta. The 2nd maxillæ are distinctly three-jointed. Legs also three-jointed. Eyes not yet apparent. Labrum more pronounced with the two lobes amalgamated.

sth day. (Fig. 4) The antennæ have partly unrolled, and all the appendages lengthened.

9th day. (Fig. 5) The maxillary plate and maxillary seta are separate up to their bases. The labrum has come forward and developed. The and maxillæ have coalesced except at their

*On the Homologies and Mechanism of the Mouth-parts of Hemiptera. Psycke, vol. 18, Feb. 1911. 
tips, and form the labium. The antennæ hang down with the legs. All the trophi are larger and more developed. The eyes are not yet visible.

10th day. (Fig. 6) The head is well formed with the eyes partly pigmented. The antennæ are long and repose in a ventral position between the first pair of legs, their basal part and the head-capsule having begun to grow forward to cover the bases of the mandibles and maxillæ. The labrum and clypeus are much longer and free. The mandibles are flattish bodies about twice as long as broad, lying above the maxillæ. The maxillary setæ have become twice the length of the mandibles and flattish, the maxillary plates have altered but little, and still retain a slight connection with the setæ at their bases. The and maxillæ have coalesced to near their tips and are more distinct.

11th day. (Fig. 7) The head is distinct and the eyes much more pigmented. The bases of the antennæ have grown more forward along with the head-capsule, and enveloped the base of the clypeal region. The labrum is elongated. The labium is one piece with three distinct joints, and a more obscure basal one.

12th day. The articulations of the mandibles to the headcapsule have begun to assume their ginglymus character.

13th day. (Fig. 8) The forward movement of the headcapsule and base of antennæ has continued considerably, the bases of the mandibles and maxillæ appearing to be within the head-capsule. 'The lateral edges of the labium have begun to turn up and form the groove in which the setæe eventually repose.

14th day. (Fig. 9) The false sutures in the head-capsule are plain, showing the forward movement of the head-capsule and its fusion with the clypeal region, leaving only the labrum and the epipharynx free. The setæ are more slender and rod-like. The labium is distinctly grooved.

15th day. The head is more chitinized and pigmented, the greatest change being the more definite shape of the maxillary plate, the dorsal edges being in contact with the lateral edges of the labrum, and its ventral edges partly fixed to the basal part of the labium. The ginglymus articulations of the mandibles are distinct. The only connection between the maxillary plate and seta is by the protractor muscle.

16th day. (Fig. 10) The forward part of the head-capsule 
has fused with the clypeus, the false sutures on the head-capsule are distinct. The retractor muscles of the setæ can be seen passing to the back of the head-capsule.

17th day. The head has become firmer; otherwise there is little change.

18th day. (Fig. 11) The pseudo-sutures across the head from eye to eye are distinct. The tips of the mandibles are barbed, and the maxillary setæ have their lateral edges turned up, and the outer sides of their tips corrugated. There are bristles on the labrum.

19th day. The maxillary setæe are three-ridged longitudinally (a central ridge, with the lateral edges turned up to form two lateral ridges).

20th day. (Fig. 12) A slight alteration in the pseudo-sutures of the head-capsule. The maxillary plates are firmer and more chitinous. Tip of mandible reaches to tip of epipharynx. Tip of maxillary seta reaches somewhat beyond tip of epipharynx. The seta-ends are still outside the labium, $i$. e., not in the trough of the labium. The lateral edges of the labium meet along dorsal central line from tip to epipharynx. The basal joint of the labium has become fused with the head capsule, the gular region and the ventral part of the maxillary plates, the only free part being a small ventral sclerite to which the retractor muscle is attached.

21st day, 9 a.m. (Fig. 13) The tips of the setæ reach a little beyond the tip of the epipharynx. The epipharynx has slightly lengthened.

21st day, noon. (Fig. 14) There are slight changes in the pseudo-sutures of the head. The seta-tips remain as before. The second joint of labium is well defined. The labrum and epipharynx are well defined.

21st day, half-hatched nymph. The occipital region, hitherto partly invaginated into the prothorax, has greatly lengthened, owing to the straightening out of the head, and become chitinous. The and joint of the labium has lengthened. The junction of the gular region with the basal joint of labium is complete. There is no line of demarcation between clypeus and labrum, but the epipharynx is distinct from the latter. The only pseudosutures remaining are those bounding the labral-clypeal region, and the deep transverse constriction between the eyes. In fact, 
the head now much resembles that of an adult, but for the further lengthening out which reduces the large epicranial lump behind the eyes. The post-embryological development is very similar to that of Sycanus croceovittatus.

Up to the time of hatching the tips of the setæ project only a little beyond the apex of the epipharynx, and are free, but as soon as the young has freed itself from the amnion the tips of the setæ are placed into the trough, and pushed beyond the tips, of the labium. It is able to do this for two reasons; one, because during development the basal part of the seta, with its tendons and muscles, has grown back into the head and formed a loop which reached even onto the prothorax (Fig. $15 \mathrm{~m}$. t. s.). This is straightened out at birth, and pushes the seta-tip through the trough of the labium. The second reason is because of a lengthening of the anterior part of the seta after casting the amnion.

These studies lead us to the following conclusions.

What is termed the frons by many writers we consider as clypeus, and their clypeus as labrum. The clypeal region is often very indistinct, and amalganated with the head-capsule. The loræe (mandibular sclerites of Meek) have no connection with the mandibles, but are lateral developments of the clypeal region. The dorsal and outer pair of setæ are the mandibles, developed direct from the first pair of appendages behind the stomodæum of the embryo, and articulated in the normal position, viz.:- on the oral margin between the clypeus and maxillæ. The ventral and inner pair of setæ are part of the maxillæ, developed directly from the distal joint of the second pair of appendages behind the stomodxum of the embryo, the basal joint being directly developed into the maxillary plate (maxillary sclerite of Meek, Maxillarhöcker of Heymons). The complete amalgamation of this portion of the maxilla with the head-capsule, leaving no line or suture of juncture, is unique among insects, and constitutes one of the most difficult points for interpretation. In many Heteroptera the maxillary plate fuses with the lateral edges of the basal labial segment. The labium is formed by the entire fusion of the and maxillæ. In many of the Heteroptera the basal joint fuses with the head-capsule and the ventral edges of the maxillary plates. The salivary syringe (salivary injector of Meek, Wanzenspritze of German writers) is homologous 

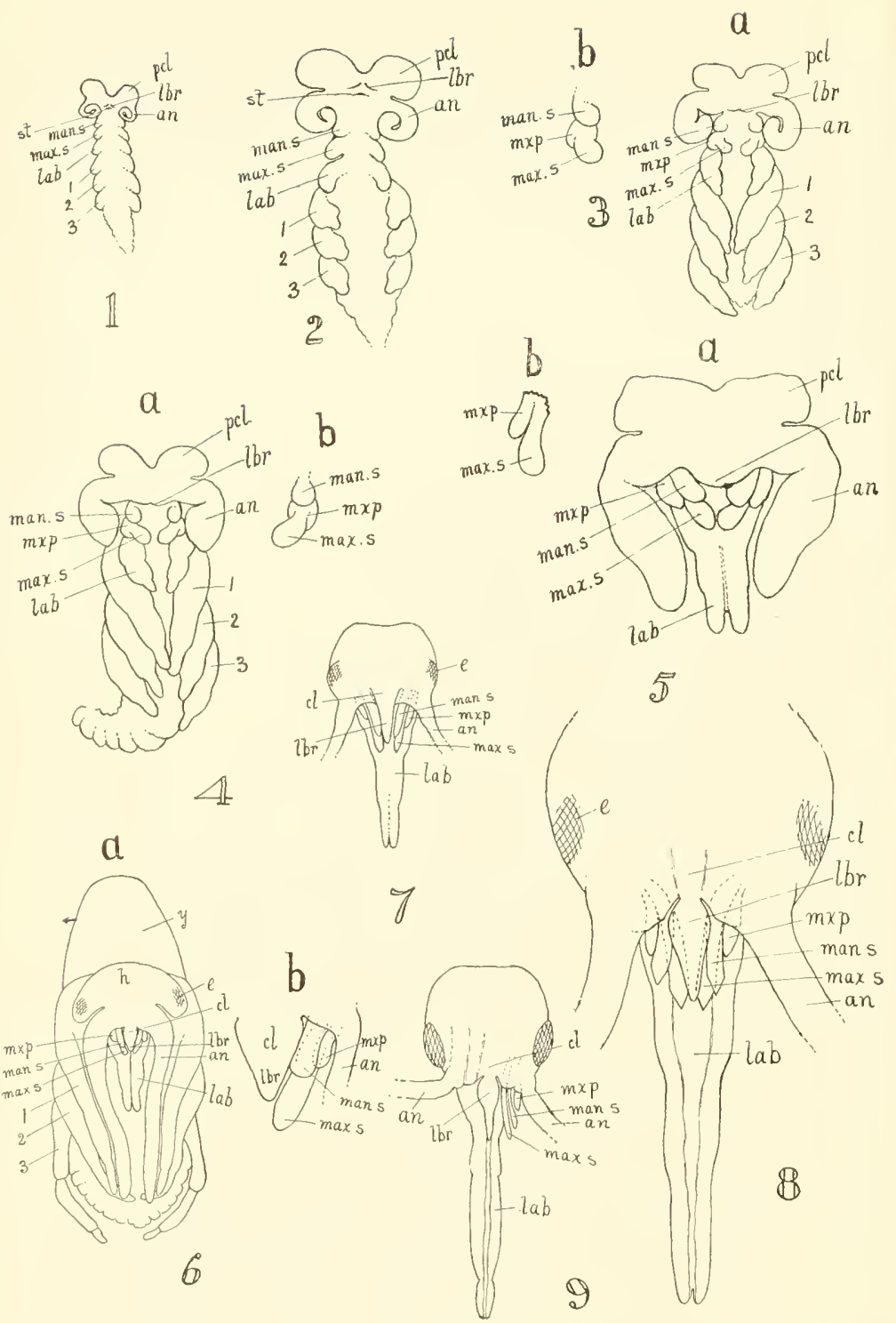


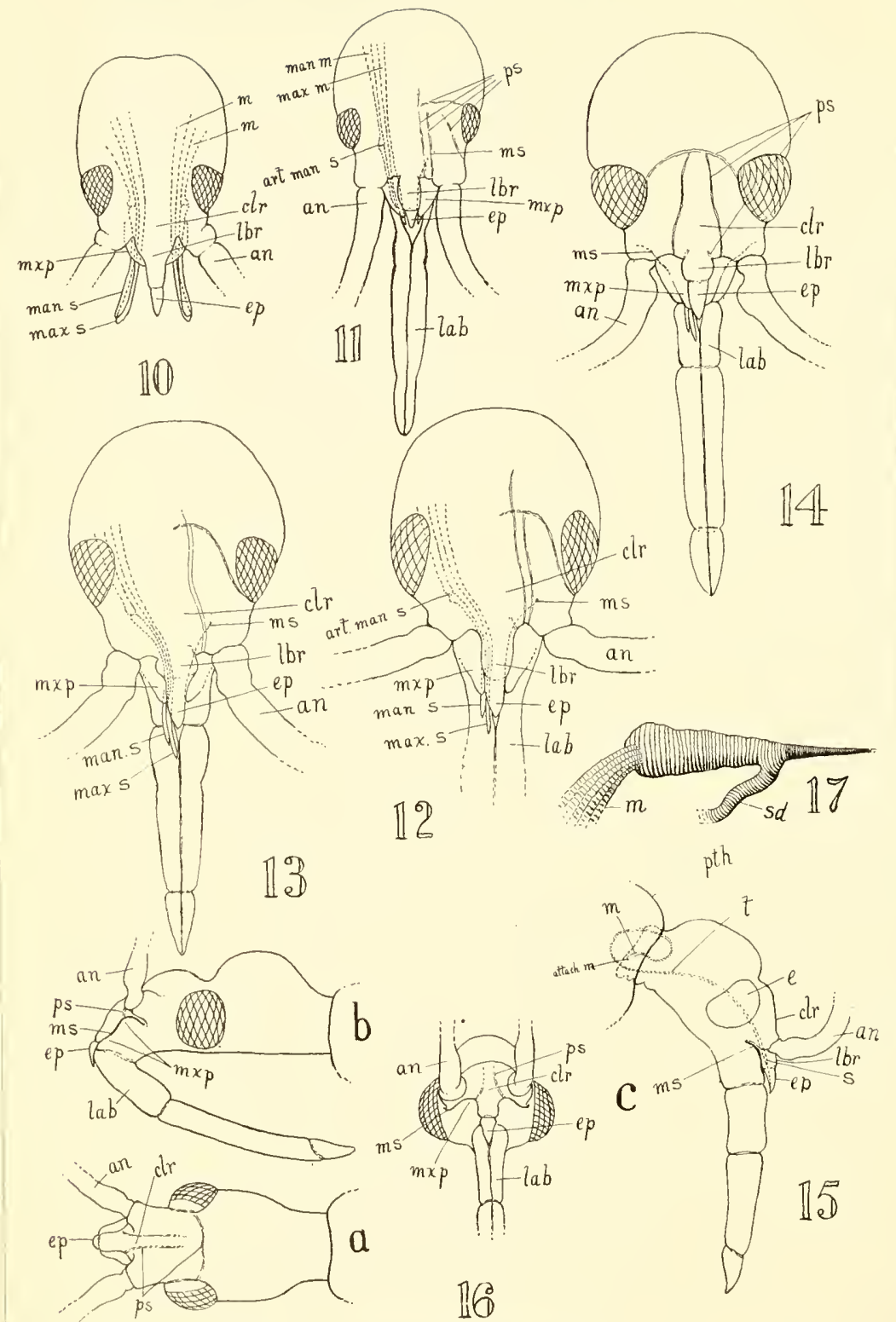


to the claustrum salivæ (Hansen) of Diptera, and is a development of the salivary ducts. This can be plainly seen in the embryo about the fifteenth day, when the syringe is in the shape of a sack-like dilation of the common salivary duct, stiffened with spiral threads, eventually becoming chitinous, and tnd whe ehere the muscle is attached invaginated (Fig. 17). Our studies gave us no chue to the missing palpi.

\section{EXPLANATION OF PLATES 9 AND 10.}

\section{Fig. 1.}

Embryo of fifth day.

\section{Fig. 2.}

Embryo of sixth day.

Fig. 3.

Embryo of seventh day; $a=$ embryo, $b=$ Right mandible and maxilla.

Fig. 4.

Embryo of eighth day; $a=$ embryo, $b=$ Left mandible and maxilla.

Fig. 5.

Head of embryo of ninth day; $a=$ head, $b=$ Right mandible and maxilla.

Fig. 6.

Embryo of tenth day; $a=$ embryo, $b=$ Left mandible and maxilla.

Fig. 7.

Head of embryo of eleventh day.

Fig. 8.

Head of embryo of thirteenth day.

Fig. 9.

Head of embryo of fourteenth day.

Fig. 10.

Head of embryo of sixteenth day.

Fig. 11.

Head of embryo of eighteenth day.

Fig. 12.

Head of embryo of twentieth day.

Fig. 13.

Head of embryo of twenty-first day, 9 a. m.

Fig. 14.

Head of embryo of twenty-first day, 12 noon.

Fig. 15.

Head of nymph of twenty-first day, when nymph is half-way out of egg.

Fig. 16.

Head of nymph when just hatched out. $a=$ dorsal view, $b=$ side view, $c=$ front view.

Fig. 17.

Salivary syringe of embryo about fifteenth day. 

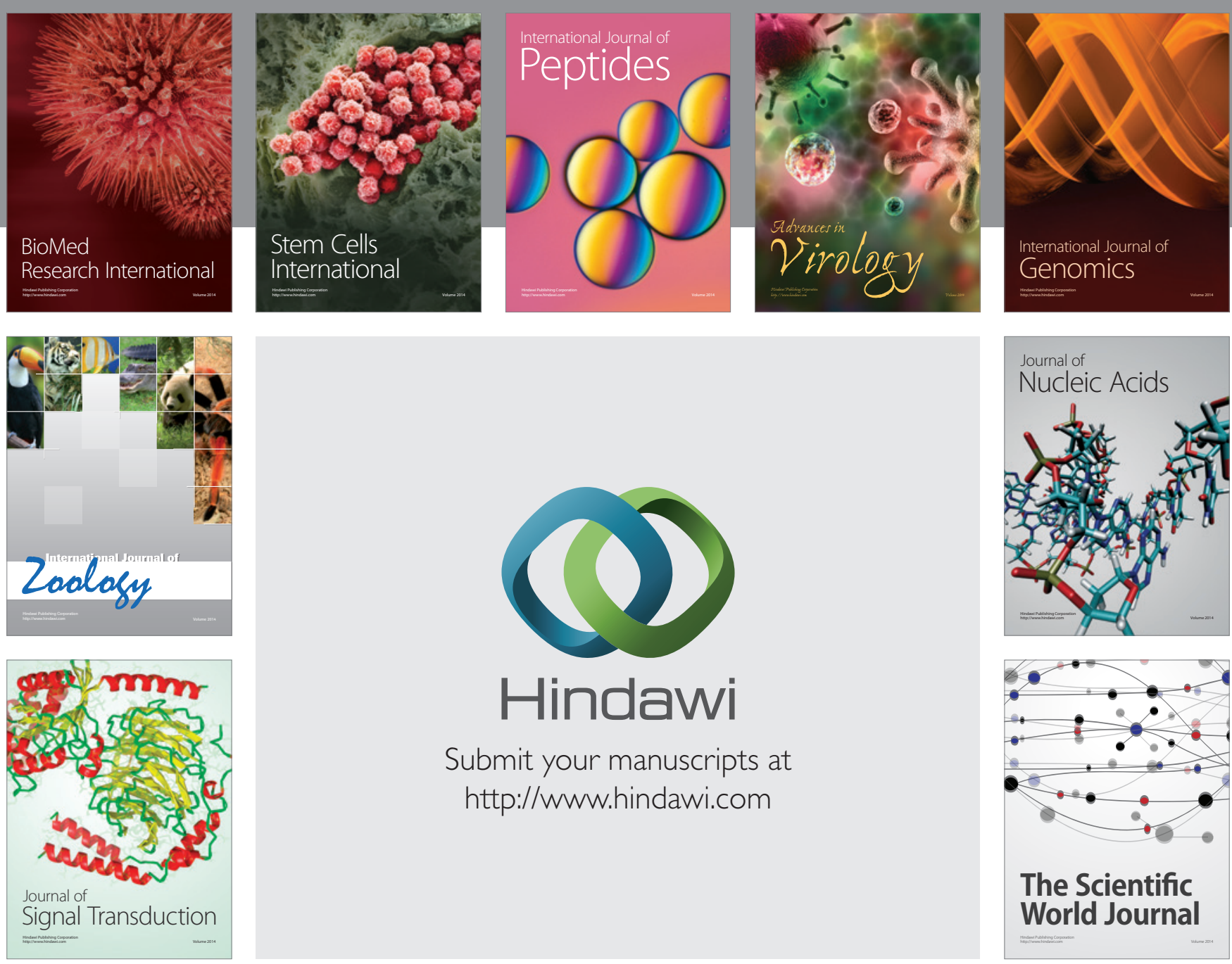

Submit your manuscripts at

http://www.hindawi.com
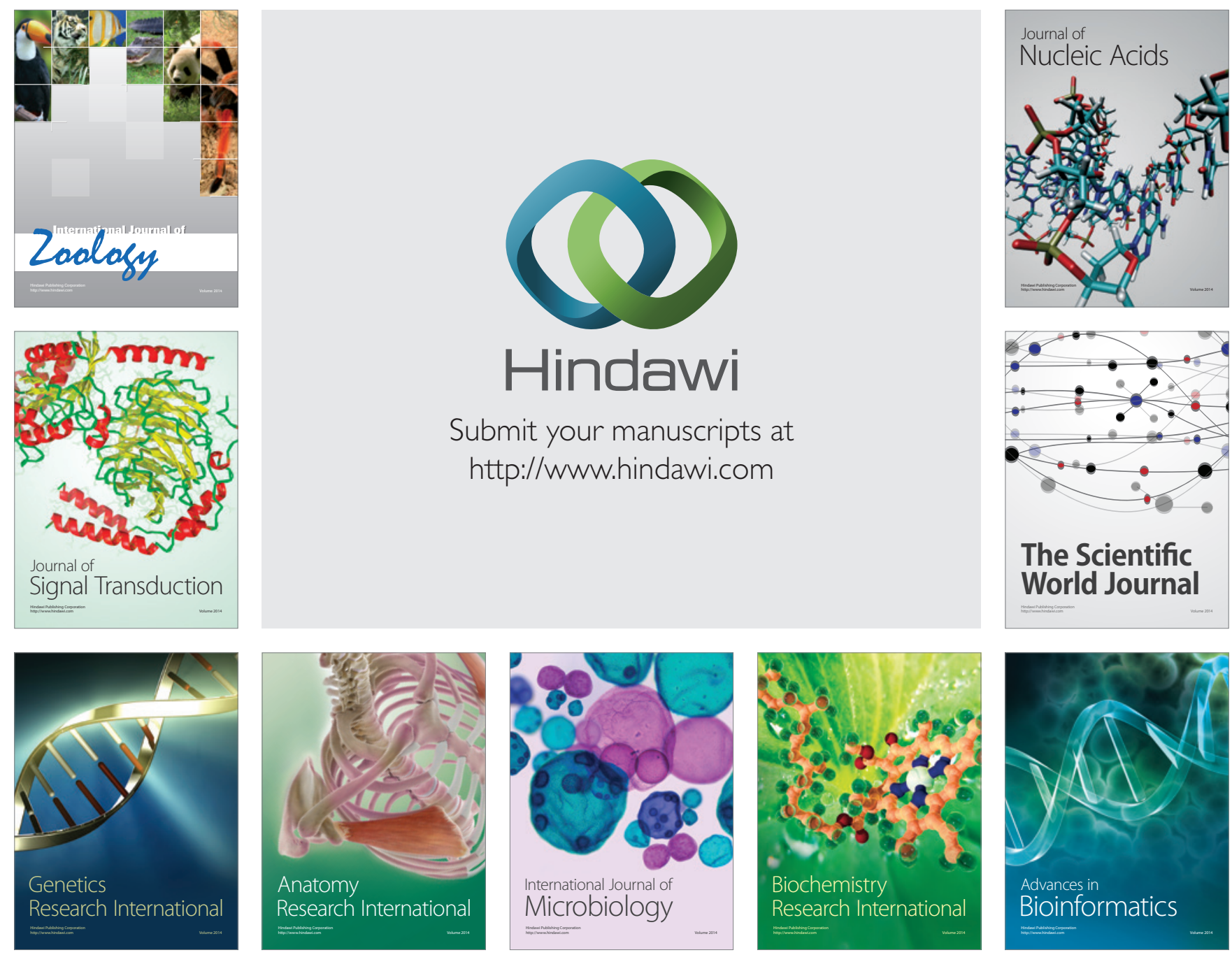

The Scientific World Journal
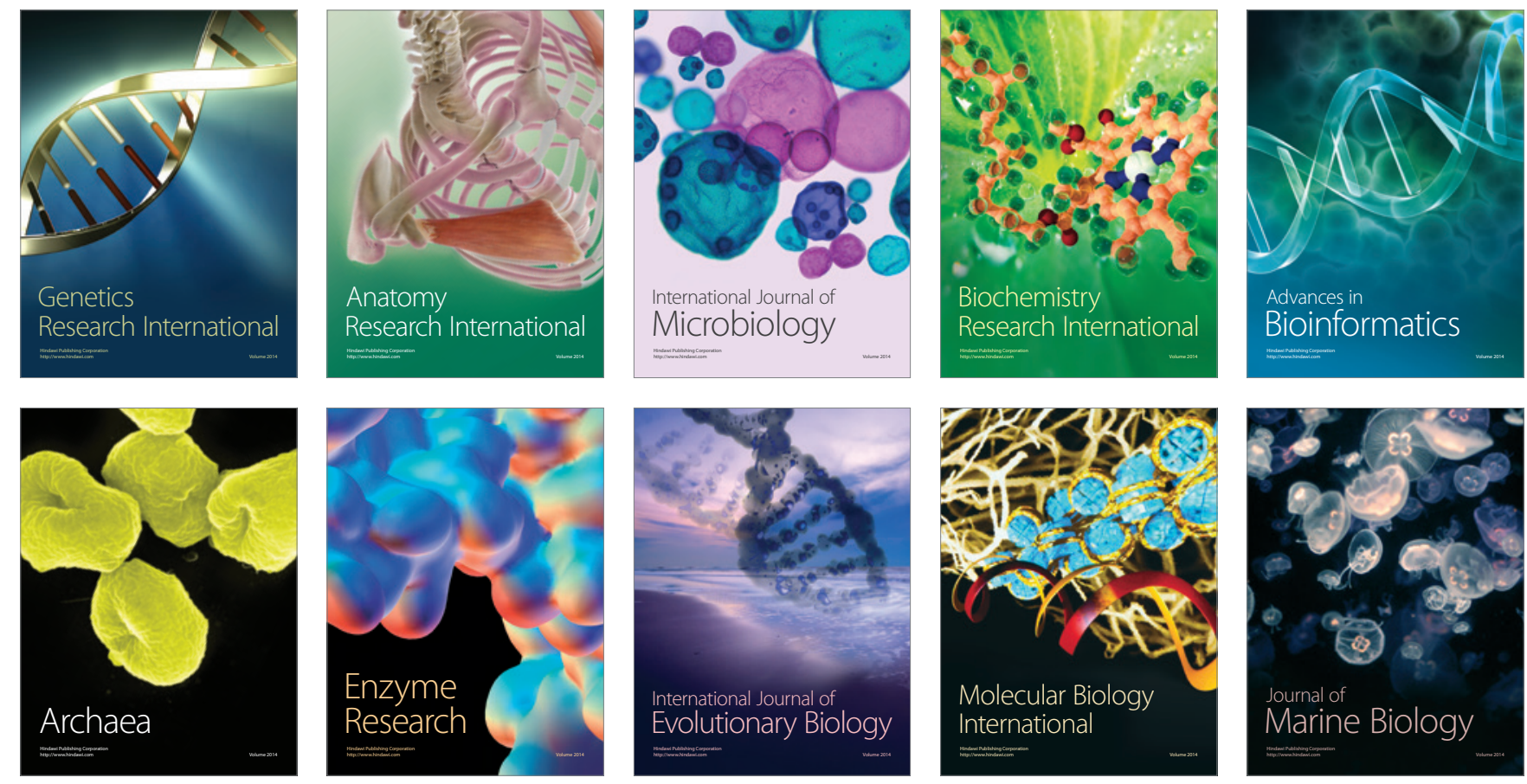